\title{
Globalization of Constitutional Law through comparative Constitution-making
}

\author{
By Francois Venter, Potchefstroom*
}

\section{Introduction}

Since the end of World War II, numerous new constitutions have been written and many have been revised. ${ }^{1}$ Constitutional systems and ideas, and therefore also written constitutions, have always tended to influence and be influenced by others. Thus e.g. the $18^{\text {th }} \mathrm{Cen}$ tury philosophical linkages between the constitutions of France and the United States are indisputable, as are the influence in the $19^{\text {th }}$ Century of the US Constitution on South American countries such as Mexico and Argentina. In the era of colonialism many parts of the world were infused with the constitutional notions of the colonial powers, especially Britain and France, though frequently in adapted forms. ${ }^{2}$ The end of World War II marks an important turning point in the history of constitution-making: the USA as primary victor emerging after the war for all practical purposes wrote the Japanese Constitution of 1947 and was a significant presence behind the work of the Parlamentarischer Rat which formulated the German Grundgesetz of 1949. After the war the scene was also set for the acceleration of the process of decolonization, not only in the underdeveloped parts of Africa, but also e.g. in the so-called British dominions of India, Canada and South Africa, causing a rash of new constitutions to be produced. The most recent wave of constitutionmaking was of course generated by the fall of the USSR, whereby the Soviet "empire" in East and Central Europe disintegrated into multiple sovereign states and the logistical and ideological grip of communism on the Third World was relieved.

The ebb and flow of constitutional ideas since the late $18^{\text {th }}$ Century have resulted in a globally shared vocabulary of constitutional structures, rights, principles and values. This convergence has particularly become evident in the process of constitution-making and revision. An interesting phenomenon in this regard is that the constitutions of many countries that are not considered to be constitutional states due to their express socialist ${ }^{3}$ or

* Professor of Law, North-west University, Potchefstroom, South Africa. E-Mail: Francois. Venter @nwu.ac.za

1 Gavin W Anderson, Constitutional Rights after Globalization (Oxford 2005), 4 note 4 lists 40 instances as a "representative sample of countries which have undergone major constitutional reform over the past 25/30 years."

Thomas M. Franck / Arun K. Thiruvengadam "International Law an Constitution-Making" 2003 Chinese Journal of International Law 467, 500-504 for a compact overview.

3 Article 1(1) of the Chinese constitution of 2004 e.g. provides "The People's Republic of China is a socialist state under the people's democratic dictatorship led by the working class and based on the alliance of workers and peasants", while in article 33(3) it is provided that "The State respects and preserves human rights." 
religious ${ }^{4}$ character, also, at least partially, employ the language of familiar to constitutionalism.

National constitution-making continues to be an internal affair of the sovereign state, but every new constitution is written on paper watermarked by a globalized conceptions of constitutionalism.

\section{Constitutional Structures}

\subsection{Sovereignty}

Constitutional law evolved, and still operates on the assumption that the state is sovereign and that it exists for the benefit and protection of its nation and the associated legal system. The key references for this assumption continue to be the famous opening words of the US Constitution of 1789 "We the People ..." and the French constitutional principle of "government of the people, by the people, for the people". ${ }^{5}$ Recent reflections of this assumption are to be found in e.g. the 2003 draft constitution of Afghanistan "We the people of Afghanistan" and article 2(1) of the Albanian Constitution of 1998 which provides that "sovereignty in the Republic of Albania belongs to the people."

If one considers the escalating tendency of the incursion of the global market (as perhaps the primary driver of globalization) on the freedom of choice of the contemporary state's policy making in many fields, the credibility of the constitutional affirmations of national sovereignty tend to suffer under the onslaught of globalization. However, the nation state and its sovereignty is far from becoming irrelevant, especially if one takes into account the fact that the degree of constitutional globalization is most frequently expressed in terms of its limitation of state sovereignty. ${ }^{6}$ Another aspect of the changes that the nation state as a phenomenon is undergoing, is the increasing pluralization of state populations brought about by demographic mobility, rendering it less convincing to refer to the population of a state as a "nation" in the ethnological or anthropological sense of the word.

Another challenge to the sovereignty of the nation state is emerging due to a changing perception of the individual. It would appear that fundamental rights, especially as they are proclaimed and protected in international law, are perceived by many as the foundation upon which individual human "sovereignty" has been established globally. This also con-

Article 2 of the Constitution of Bahrain of 2002 provides "The religion of the State is Islam. The Islamic Shari'a is a principal source for legislation", while article 18 states that "People are equal in human dignity, and citizens are equal before the law in public rights and duties. There shall be no discrimination among them on the basis of sex, origin, language, religion or creed."

Article 2 of the current Constitution of the $\mathrm{V}^{\text {th }}$ Republic of 1958.

6 Cf. e.g. John D Snethen, "The Evolution of Sovereignty and Citizenship in Western Europe: Implications for Migration and Globalization" 2000-2001 (Vol 8) Indiana Journal of Global Legal Studies 223, at 224-225. 
stitutes a concrete challenge to what is may be referred to as the Westphalian notion of the sovereignty of the state. ${ }^{7}$

This challenge is no mere academic construction, as is demonstrated by the following statement made in 1999 by the UN Secretary-General Kofi Annan in an article in The Economist ${ }^{8}$ :

State sovereignty, in its most basic sense, is being redefined ... States are now widely understood to be instruments at the service of their peoples, and not vice versa ... [while] individual sovereignty - by which I mean the fundamental freedom of each individual, enshrined in the Charter of the United Nations and subsequent international treaties - has been enhanced by a renewed and spreading consciousness of individual rights.

\subsection{Separation of powers}

Contemporary constitution-making is consistently respectful of the desirability to spread governmental authority horizontally among the three branches of government. This is almost always implied in the structure of constitutions, and is frequently expressly stated as a constitutional principle. ${ }^{9}$ Partly, but not only due to the imprecision of the doctrine, the

Doyle/Gardner, 3-4: "The foundation of the current state system - and a key feature of international relations since the seventeenth century Treaty of Westphalia - is the notion that state enjoy sovereign equality: no state has the right to interfere in the domestic affairs of another state; this is preserved as Article 2(7) of the UN Charter. However, many scholars agree that by granting rights to individuals, the conception of human rights limits state sovereignty - human rights abuses within state borders, even perpetrated by a government against its own people, are no longer matters solely within the purview of domestic affairs. Many noted experts agree with former Secretary-General Annan that a state's legitimacy is tied to proper treatment of its citizens and an offending state can no longer hide behind a mantle of sovereignty alone. This issue - the nature of the relationship between human rights and state sovereignty - lies at the core of many contemporary debates in the field: the cultural relativity of rights, international humanitarian intervention, human rights abuses as underlying causes of conflict, and how to address past abuses in post-conflict peacebuilding."

Also Cottier/Wüger, 242: "Das Verfassungsrecht steht in der Tradition des Nationalstaates. Es hat sich im Gefolge des Westfälischen Friedens von 1648 über Jahrhunderte entwickelt. Materiell kann es dahin beschrieben werden, dass es grundlegende Rechtsverhältnisse in Bezug auf ein Territorium bestimmt. Es wurde als nationalstaatliche Verfassung auch zur Verfassung im formellen Sinn. Das Recht selbst konzentrierte sich generell auf die Regelung so definierter Verhältnisse und verlor die frühere Universalität des römischen Rechts."

The Economist 18 September 1999, referred to and quoted by Michael W. Doyle and Anne-Marie Gardner in their introductory chapter of Jean-Marc Coicaud / Michael W. Doyle / Anne-Marie Gardner (eds), The Globalization of Human Rights (United Nations University Press, 2003) n 2.

Thus e.g. article 50 of the Indian Constitution of 1950 provides that "The State shall take steps to separate the judiciary from the executive in the public services of the State" and the Turkish Constitution of 1982 affirms in its preamble "[t]he principle of the separation of powers, which does not imply an order of precedence among the organs of State but refers solely to the exercising of 
effects of granting specific powers to the various branches is not always predictable. The tendency to shift constitutional emphasis from state power to the social responsibility of the state $^{10}$ is particularly evident in the escalating debate on the constitutional protection of social and economic rights. ${ }^{11}$ Be that as it may, on the frontline of the advance of enforceable socio-economic rights, the balance of powers between especially the judiciary on the one hand and the legislative and executive authorities on the other comes directly in the line of fire. ${ }^{12}$

\subsection{Constitutional adjudication}

Whereas the US Supreme Court in 1803 established its jurisdiction of judicial review in Marbury $v$ Madison on the basis of its interpretation of the Constitution and precedents in English law, the authority of courts to adjudicate all actions in terms of a supreme constitution has become the norm in contemporary constitutions. There are of course various models of constitutional adjudication and the nature of the courts or other bodies to which the jurisdiction is entrusted also varies, but contemporary states without it are the exception rather than the rule. ${ }^{13}$

Considerable scepticism about the justification of judicial review, founded upon the construction of the "counter-majoritarian dilemma" continues. ${ }^{14}$ Nevertheless, in the constitution-writing of our era the American example, inclusive of and despite the countermajoritarian difficulty, has provided foundational guidance. Thus e.g. section 81 of the Japanese Constitution of 1947 explicitly empowers the Supreme Court "to determine the constitutionality of any law, order, regulation or official act", a power which is exercised

certain State powers and discharging duties, which are limited to cooperation and division of functions, and which accepts the supremacy of the Constitution and the law."

10

This naturally also has its implications for the doctrine of the separation of powers. The vehicle for this shift is the supremacy of the Constitution: in South African jurisprudence on the enforcement of socio-economic rights (e.g. Minister of Health v Treatment Action Campaign 2002 (5) SA 721 (CC) paras [38] and [99]), the values underlying the supreme Constitution, as it is interpreted by the judiciary, override considerations of governmental preferences for the budgetary distribution of available resources, arguments of the anti-majoritarian difficulty and limited bureaucratic capacity.

Cf. e.g. Ruth Gavison, "On the relationships between civil and political rights, and social and economic rights" in Jean-Marc Coicaud / Michael W. Doyle / Anne-Marie Gardner (eds), The Globalization of Human Rights, United Nations University Press, 2003, 23-55.

12 This is demonstrated in more detail in: F. Venter, "The Politics of Constitutional Adjudication" 2005 ZaöRV (65) 129, at 155-163.

13

Cf. e.g. http://www.concourts.net/tab/introen.html (consulted on 4 July 2007).

14

Cf. e.g. DE Livel / PA Haddon / DE Roberts / RL Weaver, Constitutional Law - Cases, History and Dialogues, 1996, 9: "Criticism of the judiciary is especially intense when it strikes down legislation on grounds that it conflicts with a right or liberty not actually enumerated by the Constitution." 
with reticence, but nevertheless exercised. ${ }^{15}$ The German Grundgesetz of 1949 requires federal legislation in article 94(2) to "specify the cases in which its [the Federal Constitutional Court's] decisions have the force of law", and the relevant legislation ${ }^{16}$ renders the decisions of the Court binding on all "constitutional organs as well as on all courts and authorities." ${ }^{17}$ The South African Constitution of 1996 is construed on clear assumptions as to the status of the Constitution and its enforcement: in section 2 the supremacy of the Constitution is established and it is provided that "law or conduct inconsistent with it is invalid"; the High Court and Supreme Court of Appeal are endowed with jurisdiction on constitutional matters (sections 168 and 169), but in terms of section 167(5) "The Constitutional Court makes the final decision whether an Act of Parliament, a provincial Act or conduct of the President is constitutional . . ." Judicial constitutional review therefore appears to have been accepted towards the end of the twentieth century to be an inherent characteristic of the constitutional state.

There is also the view that in constitution-making, elites feeling threatened, support a powerful role of the judiciary as a means of preserving privileged positions in complex societies, and that "the global trend toward juristocracy is part of a broader process, whereby political and economic elites, while they profess support for democracy, attempt to insulate policymaking from the vicissitudes of democratic politics." ${ }^{18}$

It does however seem unlikely that the mechanism of judicial review would survive and flourish in constitutional democracies all around the globe if the shadows of elitism and counter-democracy undermined the emergent sovereignty of the individual. Constitutional judgments are naturally always open to criticism, either from the perspective of individual interests, governmental goals or internationally supported doctrine. In the current circumstances of vastly enhanced means and speed of communication, the exercise of judicial review in any single instance is normally almost instantly accessible to anyone interested in the subject. Although it provides no guarantee, it can in itself not but have the effect of dampening any tendencies of judicial adventurism running counter to the global constitutional ethos.

The judicial development of constitutional law through the authoritative interpretation of the Constitution is the inevitable implication of review jurisdiction. In fact, it may even

F. Venter, Constitutional Comparison - Japan, Germany, Canada and South Africa as Constitutional States, 2000, 87-90, and more recently, Koji Tonami, "Die Entwicklung der Verfassungsgerichtsbarkeit und die Probleme der richterlichen Prüfungsbefugnis über die Verfassungsmäßigkeit in Japan" in: Christian Starck (ed), Fortschritte der Verfassungsgerichtsbarkeit in der Welt - Teil I, 2004, 37-41, 15 ff.

Article 31(1) of the Bundesverfassungsgerichtsgesetz.

17

Venter, (note 15), 90-94.

18 Ran Hirschl, "The Political Origins of the New Constitutionalism", 2004 Indiana Journal of Global Legal Studies 71, 73 and "The Political Origins of Judicial Empowerment through Constitutionalisation: Lessons from Four Constitutional Revolutions", 2000 Law \& Society Inquiry 91. 
be a constitution-making tool in the sense that the actual meaning and impact of constitutional provisions are brought to life through jurisprudence. Thus, e.g. it was left to the South African Constitutional Court to determine, in the absence of explicit constitutional regulation of the point, that the Constitution prohibited the imposition of the death penalty and corporal punishment, ${ }^{19}$ thereby actually "completing" the constitution-making process. This does not occur only when a constitution is new, but almost every ground-breaking interpretative judgment of an apex court on the constitution has this effect. Some examples are the German Maastricht Urteil ${ }^{20}$, the House of Lords' recent judgement in the Al-Skeini case $^{21}$ and the Indian Supreme Court's judgment in the Minerva Mills case. ${ }^{22}$

\subsection{Decentralization / deconcentration}

Apart from the horizontal distribution of government authority, it has become a truism of constitution-making that the vertical distribution of authority is a desirable structural mechanism by which the undemocratic concentration of power may be avoided. The term "federalism" immediately comes to mind. However, the term has lost its usefulness as a means of distinguishing clearly between the structural composition of different states based only on the terminology used to describe the form of state: it is quite conceivable that a specific formal federation will show a less effective or extensive vertical distribution of authority than another non-federal state in which government authority is well distributed vertically to multiple organs of government. ${ }^{23}$

S v Makwanyane 1995 (3) SA 391 (CC); S v Williams 1995 (3) SA 632 (CC).

Judgment of the Bundesverfassungsgericht of 12 October 1993, BVerfGE 89, 155 in which the position of German sovereignty relative to the European Community was addressed inter alia. For a penetrating discussion of the continued effects of the judgment in Europe, see Julio Baquero Cruz, The Legacy of the Maastricht-Urteil and the Pluralist Movement, European University Institute, Florence - Robert Schuman Centre for Advanced Studies, Working Paper 2007/13, published on the internet at http://www.eui.eu/RSCAS/WP-Texts/07_13.pdf (downloaded on 21 July 2007).

Al-Skeini v. Secretary of State for Defence [2007] UKHL 26 (found on the internet on 13 July 2007 at http://www.publications.parliament.uk/pa/ld200607/ldjudgmt/jd070613/skeini-1.htm in which the Law Lords ruled that Iraqi civilians arrested and detained by British soldiers in Iraq could rely on the protection of the Human Rights Act. Para 8 of the judgment reads: "The HRA is a statute enacted by Parliament. Where an issue arises as to its meaning, it must be construed. This is a task which only a UK court can perform. The court in Strasbourg is the ultimate authority on interpretation of the European Convention, but it cannot rule on the interpretation of a domestic statute."

Minerva Mills v. Union of India 1980 AIR 17891981 SCR (1) 2061980 SCC (3) 625 in which its doctrine that Parliament was not empowered by the Constitution to alter "the basic structure of the Constitution" was re-established in the face of government opposition.

Cf Schneider, Föderale Verfassungspolitik für eine Europäische Union,1996, 45 at 48: Classic constitutional theory purported to divide all states into one of two contrasted types, the unitary and the federal, depending on whether sovereignty was undivided or shared between levels of government. In the post-war years this dichotomy has been broken by the appearance in Western Europe 
It would appear that, in contemporary constitution-writing, the need for decentralization or deconcentration is more prominent than for the creation of federal states out of previously autonomous or sovereign entities. More frequently there is a need for the accommodation of regional, ethnic or other interests within a single state, or simply for the prevention of a concentration of power at national level. Of this, the complexities of the Russian Federation may be considered an example. ${ }^{24}$ Nevertheless, a structured and balanced constitutional allocation of authority to national and local, and frequently also regional centres of power tends to be the norm. Although globalized constitution-making has not reached a point where a composite form of state can be seen as a universal structural standard, indications are that contemporary constitutionalism strongly favours decentralization. The most prominent example is France, traditionally the primary example of the unitary European state, which has over the recent decades embarked on a process of decentralization of state authority in favour of regional and municipal government. ${ }^{25}$

\section{Rights}

A Charter, Bill or Declaration of Rights as part of, or contiguous to newly made constitutions has become the norm for constitution makers. Whereas this generally has the effect of the spread of fundamental rights doctrine, there are also cases of constitutional systems being strange bedfellows of rights provisions in the constitution. In socialist constitutions rights are e.g. directly associated with duties ${ }^{26}$ or heavily qualified by the authority of the state $^{27}$ and in the constitutions of Islamic states the protection of religious freedom stands in stark contrast to the explicit exclusive state promotion of Islam. ${ }^{28}$

of an intermediate type, the regional state, in which ultimate sovereignty rests with the centre (as in a unitary state) but the Constitution also recognises regional communities and accords them an inviolable status and a range of exclusive powers which are constitutionally entrenched (as in federalism).

Cf. e.g. Cameron Ross, in: Mike Bowker / Cameron Ross (eds), Russia after the Cold War, 2000, Chapter 4, at 99: " ... it is clear that Russian federalism is in deep crisis. There would appear to be almost as many kinds of federal relations as there are subjects of the federation. ... the greatest threat to the federation does not come in the main from ethnic separatists, but from the reicher regions which seek ever more economic and legal autonomy." tity Construction" 2006, 4, French Politics 31-57.

Thus e.g. the right to work is granted in the same provision in which the duty to work is imposed on citizens in the constitutions of Vietnam (2001, article 55(1)) and China (1982, article 42). It is however interesting to note that the preamble to the French Constitution of 1946 also stated that "Each person has the duty to work and the right to employment."

27 Article 13(2) of the Chinese Constitution of 1982 provides "The State, in accordance with law, protects the rights of citizens to private property and to its inheritance." In contrast thereto, article 6(2) provides: "The basis of the socialist economic system of the People's Republic of China is socialist public ownership of the means of production, namely, ownership by the whole people and collective ownership by the working people. The system of socialist public ownership super- 
Various authors ascribe the increasing internationalization of constitutional law primarily to the effect that human rights doctrine has on constitutional practice. ${ }^{29}$ The adoption of the mechanism of constitutionally entrenched fundamental rights is not only evident in countries where profound constitutional transformations occur, but also in established democracies that had gone without modern charters of rights, the prime example of course being the adoption in 1998 of the British Human Rights Act. Against this background Anderson $^{30}$ draws the inference that

[t]he argument that rights constitutionalism has gone global is further supported by the growing use of comparative sources, leading to a more 'cosmopolitan' approach to constitutional adjudication. In its strongest version, it is said that we are witnessing the emergence of universal principles of constitutional law guiding the formation and execution of public policy.

In a thorough comparative study of the impact of international law on constitution-making, Franck and Thiruvengadam ${ }^{31}$ found that the relevance of the incorporation of the everexpanding body of international law into national law by means of constitutional provision, has become inescapable, and that -

If there is one substantive area where most states have shown great willingness to be open to principles of international law, it has been in the area of human rights.

sedes the system of exploitation of man by man; it applies the principle of 'from each according to his ability, to each according to his work'."

The Constitution of Pakistan of 1973 e.g provides in Part I article 2: "Islam shall be the State religion of Pakistan." This bland statement is put into context in an Annex named "The Objectives Resolution" which opens with the words: "Whereas sovereignty over the entire universe belongs to Allah Almighty alone and the authority which He has delegated to the State of Pakistan, through its people for being exercised within the limits prescribed by Him is a sacred trust." In Part II, article 20 provides: "Subject to law, public order and morality:- (a) every citizen shall have the right to profess, practise and propagate his religion; and (b) every religious denomination and every sect thereof shall have the right to establish, maintain and manage its religious institutions."

Brun-Otto Bryde, "The Constitutional Judge and the International Constitutionalist Dialogue" 2005 (80:203), Tulane Law Review 203, 208: "If constitutional law is no longer a parochial subject, but has become an international one, the main reason is the development of international human rights law." Ernst-Ulrich Petersmann provides a particularly penetrating exposition of this process in his contribution "Morality, Human Rights and International Economic Law: Towards Cosmopolitan Market Integration Law" in: H.-D. Assmann / R. Sethe (eds), Recht und Ethos im Zeitalter der Globalisierung, 2004, 53-86. At 58 he writes: "Justice is becoming a matter of universal and 'inalienable' human rights, democratic governance and positive national and international constitutional law in order to empower and protect individual and democratic self-development across frontiers."

Gavin W. Anderson, Constitutional Rights after Globalization, 2005, 5.

31

Thomas M. Franck / Arun K. Thiruvengadam, "International Law an Constitution-Making" 2003 Chinese Journal of International Law 467, 469-470 and 518. 
The natural law philosophy underpinning human rights doctrine promotes the notion that the documentation of fundamental rights in a constitution is merely an incidental application to the political community whose constitution it is, without derogating from the universal currency of the rights. ${ }^{32}$ From such a position, it is but a short leap towards the acceptance of the predominance of international human rights law over national norms. It is obvious from the divergent conceptions of human rights in the world that global acceptance of such predominance of international human rights has not yet been achieved. No consensus exists e.g. among Muslim scholars on the acceptability of human rights doctrine, ${ }^{33}$ nor has the accusation from oriental scources that the West is attempting to enforce its human rights values on the East approached closure. ${ }^{34}$ Nevertheless, constitutional rights language in recently drafted constitutions tends toward similarity, although the interpretation of similar terms may vary in different jurisdictions. ${ }^{35}$

Since the adoption of the International Convention on Economic, Social and Cultural Rights, ${ }^{36}$ social and economic (or socio-economic) rights as constitutionally entrenched, justiciable and enforceable fundamental rights have been established in some Latin American jurisdictions and in India and South Africa. Their global recognition as such is however far from complete. Progress in this direction is however evident from the discussions at the United Nations on the adoption of an optional protocol to the CESCR, in terms of which

Francis Cheneval, "Constitutionalizing Multilateral Democratic Integration" in: Philippe Mastronardi / Denis Taubert (eds.), Staats- und Verfassungstheorie im Spannungsfeld der Disziplinen ARSP Beiheft Nr. 105 30, 31 e.g. writes: "Human and civil rights as well as a system of justice based on universal validity claims are a source of cosmopolitan transcendence. State constitutions only realize fundamental rights for a particular community of citizens or people residing on a particular territory. They are incomplete with regard to their own claims because they are the foundational document of a particular political community but transcend the political singularity by reference to the normative fiction of a moral, legal, and ultimately political community of mankind. Constitutions found a specific political entity but legitimate it with universal principles that imply a cosmopolitan transcendence towards an ever more universal realization of human ideals."

Cf e.g. Ahmad S. Moussalli, The Islamic Quest for Democracy, Pluralism, and Human Rights, 2001, whose 28 page introduction contests various other Muslim authors' points of view in this regard.

Cf Tatsuo Inoue, "Human Rights and Asian Values" in: Jean-Marc Coicaud / Michael W. Doyle / Anne-Marie Gardner (eds), The Globalization of Human Rights, 2003, Chapter 4.

An example is the meaning given to "equality" by the South African Constitutional Court. J Moseneke in Minister of Finance and others v Van Heerden 2004 (6) SA 121 (CC) e.g. stated (at para [30]): "... our constitutional understanding of equality includes ... 'remedial or restitutionary equality'. Such measures are not in themselves a deviation from, or invasive of, the right to equality guaranteed by the Constitution. They are not 'reverse discrimination' or 'positive discrimination' ... They are integral to the reach of our equality protection. In other words, the provisions of s 9(1) and s 9(2) are complementary; both contribute to the constitutional goal of achieving equality to ensure 'full and equal enjoyment of all rights'. A disjunctive or oppositional reading of the two subsections would frustrate the foundational equality objective of the Constitution and its broader social justice imperatives." 
elements of international justiciability may become possible. For present purposes it is significant that the jurisprudence on socio-economic rights and their enforceability against the state is expanding, thus increasing the likelihood that drafters of constitutions may be influenced to follow suit.

It is significant that the constitutionalization of socio-economic rights has progressed further in constitutional states with populations characterized by large numbers of poor and underprivileged people. The obvious reason for this is that the state is under such circumstances called upon more urgently to address the social discrepancies and to provide for the protection and promotion of the vulnerable components of society. In the more affluent states, the emphasis seems to be more on the provision of social security than on upliftment. Acceptance of socio-economic rights as subjectively enforceable and justiciable rights still seems to be remote in the European context. At best they are recognized as legal principles that courts may apply in the adjudication of legal norms that are inconsistent with them. ${ }^{37}$

\section{Principles}

Constitution-making is doubtlessly a process guided by the foundational thinking of the bearers of the pouvoir constituant. This was particularly clear from the powerful influences that political philosophy exerted on the $18^{\text {th }}$ Century American and French Revolutions and the constitutional documents to which they gave birth. In more recent constitution-making processes, the mechanism of prescribing a set of binding principles of constitutionalism to the authors of the new constitution has been employed in a few cases.

At the end of World War II in 1945, the former German Reich found itself occupied and administered by the military commanders of the four Allied Powers, the United States of America, Britain, France and the USSR. After it became clear at a Four Power Conference in London in 1947 that the eastern part of Germany occupied by the USSR could not for the foreseeable future be included in the constitutional reconstruction of Germany, the three western Allies instructed the eleven West-German Länder governments in 1948 to have a national constitution-writing body draw up a new constitution conforming to the requirements of democracy, federalism and guaranteed individual rights. In less than eight months the text of the new Grundgesetz, was formulated and adopted by the Parlamentarischer Rat in May 1949, whereafter it was approved by the three military governors and submitted to the various Landtage for approval. Under the circumstances it may be asked whether the Parlamentarischer Rat exercised the pouvoir constituant and if so, how it could be bound by the instructions of the Allied Powers. It is worth noting that the allied powers, Britain, the United States and France, that set the framework of principles for the 
new constitution, are the prime representatives of the historic emergence of modern constitutionalism.

Some 34 years later a set of 8 constitutional principles ${ }^{38}$ for the adoption of an independence constitution for Namibia was sponsored, again by the United States, the United Kingdom and France, but also by Canada and Western Germany. All parties interested in the writing of the independence constitution agreed to those 8 principles in 1982. Eventually the Principles were translated by a constituent assembly into a well-formulated modern constitution which came into operation in 1990.

In South Africa a two-phased constitution-making process was followed: the first Constitution was one negotiated word-for-word and formally adopted by the parliament as it was still constituted under the previous dispensation. This 1993 Constitution authorized the production of a "final" constitution in accordance with an unamendable set of 34 Constitutional Principles clothed with foundational authority in that the "final constitution" had to be certified by the Constitutional Court as being in compliance in all respects with the Principles. This eventually led to the adoption of the 1996 Constitution, but only after the Constitutional Court had, in a wide-ranging judgment, ${ }^{39}$ referred the first draft back for the

1. Namibia will be a unitary, sovereign, and democratic state.

2. The Constitution will be the supreme law of the State. It may be amended only by a designated process involving the legislature and/or votes cast in a popular referendum.

3. The Constitution will determine the organization and powers of all levels of government. It will provide for a system of governance with three branches; an elected executive branch which will be responsible to the legislative branch; a legislative branch to be elected by universal and equal suffrage which will be responsible for the passage of all laws; and an independent judicial branch which will be responsible for the interpretation of the Constitution and for ensuring its supremacy and the authority of the law. The executive and legislative branches will be constituted by periodic and genuine elections which will be held by secret vote.

4. The electoral system will be consistent with the principles in A.1 above.

5. there will be a declaration of fundamental rights, which will include the rights to life, personal liberty and freedom of movement; to freedom of conscience; to freedom of expression, including freedom of speech and a free press; to freedom of assembly and association, including political parties and trade unions; to due process and equality before the law; to protection from arbitrary depravation of private property or deprivation of private property without just compensation; and to freedom from racial, ethnic, religious or sexual discrimination. The declaration of rights will be consistent with the provisions of the Universal Declaration of Human Rights. Aggrieved individuals will be entitled to have the courts adjudicate and enforce these rights.

6 . It will be forbidden to create criminal offenses with retrospective effect or to provide for increased penalties with retrospective effect.

7. Provisions will be made for the balanced structure of the public service, the police service and defence services and for equal access by all to recruitment of these services. The fair administration of personnel policy in relation to these services will be assured by appropriate independent bodies.

8. Provisions will be made for the establishment of elected council for local and/or regional administration.

In re: Certification of the Constitution of the Republic of South Africa, 1996 (4) SA 744 (CC). 
purposes of adapting it to conform to the Principles. This process differed from the examples of Germany and Namibia in that the binding Constitutional Principles were not externally imposed, but autochthonously negotiated and quite comprehensive. Some of the Principles were couched in equivocal and generalised terms while others were crisp and concise. The Principles required inter alia the following elements to be contained in the "final" constitution:

- a democratic system of government, including multi-party democracy, regular elections and universal adult suffrage;

- the separation of powers between the legislature, executive and judiciary, with appropriate checks and balances;

- the structuring of government in three tiers, involving democratic representation at each level;

- an independent and impartial judiciary with the jurisdiction to safeguard and enforce the Constitution;

- supremacy of the Constitution, also binding all organs of state;

- special procedures involving special majorities required for the amendment of the Constitution;

- universally accepted fundamental rights, freedoms and civil liberties, protected by entrenched and justiciable provisions in the Constitution;

- equality of all before the law and an equitable legal process;

- open and accountable public administration, and

- formal legislative procedures.

These principles of constitution-making essentially reflect what might be described as the essence of contemporary constitutionalism, or of the predominant notion of a well-ordered state, Rechtsstaatlichkeit, or sometimes also (less acurately) referred to as "the rule of law".

Although all three examples of the predetermination of principles for constitutionwriting led to generally highly acclaimed constitutional documents, it cannot be concluded that such an approach will guarantee success. After all, constitutions are written for specific circumstances and formulated by bodies uniquely responsible for distinctive situations and the product and its effects can never be immutable indefinitely. Constitutional law is dynamic, even in cases where constitutional texts remain static for long periods of time. However, the formulation of an objective framework of principles as a guide for constitution-making has proven itself to be an effective approach. It will also tend to promote the incorporation of globally endorsed elements of constitutionalism.

\section{Foundational values}

If the principles of the constitutional state have achieved or are achieving the status of universal guidelines for constitution-making, one may justifiably enquire if there is a foundational Leitmotiv or set of guiding standards for constitution-making in our time. The 
notion of global values presents itself as the obvious candidate. In contemporary constitutions the values upon which the state is said to be founded, are frequently expounded in express terms. Often preambles are used for this purpose, but also other provisions in the document. A few randomly selected examples are Brazil, ${ }^{40}$ the Czech Republic, ${ }^{41}$ Finland, ${ }^{42}$ Namibia $^{43}$ and Paraguay. ${ }^{44}$ The values expressly enumerated in these examples include liberty, development, equality, justice, human dignity, peace and the enshrinement of fundamental rights. The enumerated constitutional values found in these constitutions are wide-ranging, but one that has emerged as the pre-eminent, often even unwritten value underlying constitutions, is human dignity.

The legal ethos not only of states, but of the global community is also frequently expressed in terms of human dignity. The first paragraph of the preamble of the Universal Declaration of Human Rights of 1948 e.g. states that:

... recognition of the inherent dignity and of the equal and inalienable rights of all members of the human family is the foundation of freedom, justice and peace in the world ....

and article 5 of the African Charter on Human and People's Rights of 1981 provides:

Every individual shall have the right to the respect of the dignity inherent in a human being and to the recognition of his legal status.

In the cases of the German Grundgesetz and the South African Constitution of 1996, substantive foundational provisions elevated constitutional values, and particularly human dignity, to a level of key importance.

The German Grundgesetz isolates, and therefore emphasizes, human dignity as fundamental constitutional value by providing in article 1(1): "Human dignity is inviolable. To respect and protect it is the duty of all state authority." In article 1(2)GG human rights, peace and justice are also acknowledged, clearly in support of and not in competition with

40

In the preamble of the Constitution of $1988 "$ "... social and individual rights, liberty, security, well being, development, equality and justice" are recognized as "supreme values of a fraternal. pluralist and unprejudiced society".

41 The preamble of the Czech Constitution expresses the resolve "to build, protect and develop the Czech Republic in the spirit of the inviolable values of human dignity and freedom."

42 Section 1(2) of the Finnish Constitution of 1999 provides that: "the constitution shall guarantee the inviolability of human dignity and the freedom and rights of the individual and promote justice in society."

43 The preamble of the Namibian Constitution of 1990 opens with the words: "Whereas recognition of the inherent dignity and the equal and inalienable rights of all members of the human family is indispensable for freedom, justice and peace."

44

The preamble of the Constitution of Paraguay of 1992 recognizes "human dignity for the purpose of ensuring freedom, equality and justice." 
human dignity. It is furthermore established law that the fundamental rights of the $G G$ are all vehicles of values. 45

According to the quoted statement of the BVerfG in Kalkar I, the duty of the organs of the state to exercise their authority in a manner that will ensure that fundamental rights are respected, is founded upon the express constitutional injunction that they should respect and protect human dignity. This clearly demonstrates the centrality of human dignity as constitutional value in German constitutional law. The philosophical roots of the high constitutional regard in which human dignity is held, must no doubt be ascribed to the Christian foundations upon which Western civilization was built. ${ }^{46}$ These Christian roots of the recognition of human dignity is not presented in legal doctrine as a moral or religious argument for the state's conduct to be measured against Christian standards, but Christianity is merely recognized as the factual historical origin of the concept. Secularized humanistic, Marxist, existentialist and behaviouristic and other approaches to human dignity naturally exist, each with a different, though related, philosophical emphasis. One should therefore not expect that the constitutional recognition and elevation of human dignity

A free translation of a dictum in the "Kalkar I" judgment BVerfGE 49,89 at 141-142 reads as follows:

“... According to consistent jurisprudence of the Federal Constitutional Court the protection provided by the fundamental rights does not only contain subjective defensive rights of the individual against public authority, but they simultaneously constitute constitutional value judgments of objective law that apply to all reaches of the legal order providing guidelines for the legislature, executive and the judiciary. The clearest expression of this is to be found in the second sentence of article 1(1) GG in terms of which it is the duty of all government authority to respect and protect human dignity. Constitutional obligations of protection may thus be engendered whereby it is directed that legal arrangements must be designed in such a manner that the danger of impingement of fundamental rights is also contained ..."

In their commentary "Grundgesetz für die Bundesrepublik Deutschland", 4th ed. (1997) 16-17 Jarrass/Pieroth point out that various terms have been used to indicate this value-determining aspect of the fundamental rights, viz. objektiv-rechtliche Wertentscheidungen, objektive Normen, Prinzipien and the institutionelle Gehalt of the fundamental rights.

Cf. e.g. Christian Starck in: von Mangoldt/Klein/Starck, Das Bonner Grundgesetz 4th. ed.(1999), vol. I, 34-36 and Josef Isensee, "Menschenwürde: die säkulare Gesellschaft auf der Suche nach dem Absoluten", Archiv des öffentlichen Rechts, vol. 131(2006), Vol. 2, 173, 199-209. These authors separately show how human dignity, which is now dealt with as the moral foundation, kind of "civil religion" of the secularized society, originates in the biblical teaching that man was created in the image of God, and that there is a personal relationship between God and man which is manifested in the immortality of the soul. The notions of guilt and redemption require the acknowledgement of individual freedom, which also leads to the construction of equality and fraternity on the basis of the assumption that all people were equally created in the image of God. Thus the self-determination of the individual must be founded in the worth of every person. People are therefore constrained to recognize not only their own dignity, but also to acknowledge the equal dignity of others. The state is required to provide legal recognition of human dignity and to respect and protect it. 
would ensure the emergence of a monolithic notion of human dignity. Its exact meaning can not be universally defined. ${ }^{47}$

In the South African case, human dignity is mentioned as the first of a range of constitutional values. ${ }^{48}$

The wording of section 10 of the 1996 Constitution, under the heading "human dignity" gives expression to the supposition that human dignity is not in need of being created consitutionally, but that it exists independently of the law. It reads: "Everyone has inherent dignity and the right to have their dignity respected and protected." The purport of the phrase is that human dignity is an inalienable, inborn characteristic of each individual person.

Dogmatically the recognition of human dignity is therefore not dependent upon its incorporation in a constitution. In the recent South African constitutional jurisprudence, much reliance was placed on comparative foreign judgments, e.g. those of the US Supreme Court, ${ }^{49}$ to affirm this position. The Court found further confirmation in the jurisprudence

Cf. e.g. Egan v Canada (1995) 29 CRR (2d) 79 at 106: "Dignity [is] a notoriously elusive concept ... It needs precision and elaboration."

Section 1 of the South African Constitution provides as follows:

The Republic of South Africa is one, sovereign, democratic state founded on the following values:

(a) Human dignity, the achievement of equality and the advancement of human rights and freedoms.

(b) Non-racialism and non-sexism.

(c) Supremacy of the constitution and the rule of law.

(d) Universal adult suffrage, a national common voters roll, regular elections and a multi-party system of democratic government, to ensure accountability, responsiveness and openness.

Various other provisions of the 1996 Constitution are worded with express or implied reference to section 1. Thus section 143(2) expressly requires provincial constitutions to "comply with the values in section 1"; section 7(1) states that the Bill of Rights "affirms the democratic values of human dignity, equality and freedom"; the very important section 36(1) provides: "The rights in the Bill of Rights may be limited only in terms of law of general application to the extent that the limitation is reasonable and justifiable in an open and democratic society based on human dignity, equality and freedom ...", and the equally important interpretation clause in section 39(1) provides: " When interpreting the Bill of Rights, a court, tribunal or forum - (a) must promote the values that underlie an open and democratic society based on human dignity, equality and freedom."

Although section 1 is indeed foundational, it is not the only provision in the Constitution which introduces values. Thus section 195 introduces "basic values and principles governing public administration," by prescribing in subsection (1) that "[p]ublic administration must be governed by the democratic values and principles enshrined in the Constitution" and then adding a comprehensive additional list of "principles". Furthermore Chapter 3 of the Constitution is devoted in full to introduce and regulate the notion of "co-operative government" which might be described as a set of structural constitutional values intended to determine inter-governmental relations, i.e. between and among the national, provincial and local spheres of government. 
of the German Bundesverfassungsgericht, ${ }^{50}$ the Canadian Supreme Court ${ }^{51}$ and the Hungarian Constitutional Court. ${ }^{52}$ The approach followed by the bench indicates an assumption that human dignity is the universal value which is foundational to a constitutional state and its characteristic protection of fundamental rights.

In the context of the phenomenon of the "migration of constitutional ideas", Mayo Moran maintains that in jurisdictions such as Canada, the United Kingdom and South Africa, due to the influential authority of constitutional values, "courts and commentators draw on a transnational judicial and academic conversation in order to forge responses within domestic constitutional orders." She demonstrates this with reference to the "estoppel-like effect" that the values underlying and expressed in constitutionally entrenched rights have in those jurisdictions (in contrast to the United States) by the radiation of the values into the field of rights in private relationships, e.g. libel law. ${ }^{53}$ This is an interesting field of investigation which is opened up widely by the effects of the globalization of constitutional law. It can also be expected to influence future constitution-making, at least as a conceptual development which needs consideration regarding the formulation of provisions concerning the scope of fundamental rights.

\section{Conclusion}

Do the strong indications that the drafting of constitutions in this century has inevitably become a comparative exercise due to the global tendency towards common constitutional vocabulary, principles and values lead one to the conclusion that future constitutions may simply become replicas of each other? Such an inference is not justified. Globalised constitutionalism would have to become a powerful supra-national regime to have such an effect, which would really mean the replacement of constitutional law with pervasive international legal norms. What stands between internationalism and constitutionalism as we know it, is the element of state sovereignty as cornerstone both of international law and constitutional law. Constitutions designed for unique situations may be expected to be produced for as long as state sovereignty retains its foundational importance. Nevertheless, comparative constitution-making has become an essential characteristic of the process of the drafting (and revision) of legitimate contemporary constitutions.

50

51

In par [60] et seq reference is made to the judgment in Kindler v Canada (1992) 6 CRR (2d) 193 SC.

52

53

In par [83] reference is made to the Hungarian Court's Decision No. 23/1990 (X.31.).

Mayo Moran, "Inimical to constitutional values: complex migrations of constitutional rights" in:

Sujit Choudry (ed), The Migration of Constitutional Ideas, Cambridge UP 2006, 233. 